\title{
Fibronectin biosynthesis: influence on fibroblast adhesion during chick embryo development
}

\author{
J Botti, E Gouet, R Moutsita, MA Doyennette-Moyne, \\ $M$ Aubery, P Codogno
}

UFR Biomédicale des Saints-Pères, INSERM U180, Laboratoire de Biologie et Pathologie
Moléculaires des Glycoprotéines, 45, rue des Saints-Pères, 75006 Paris, France

(15th meeting of the INRA development group, Paris, 24-26 May 1989)

\begin{abstract}
Summary - Eight $d(8 d)$ and 16d (16d) chick embryo fibroblasts (CEF) exhibited marked differences in their adhesive capacity on plastic support, but not on fibronectin substratum. This suggests differences in fibronectin (FN) expression and/or FN receptor expression. Both $8 \mathrm{~d}$ and $16 \mathrm{~d}$ CEF expressed an identical number of membrane receptors for FN with similar affinity. In contrast, the newly synthesized FN appeared de novo in $30 \mathrm{~min}$ in $8 \mathrm{~d}$ CEF versus $60 \mathrm{~min}$ in $16 \mathrm{~d}$ CEF. This difference is not due to a modification of the polypeptide chain biosynthetic rate. The FN synthesized in 8d CEF became unsensitive to endo $\beta$ - $N$-acetyl-glucosaminidase $H$ (endo $H$ ) treatment after 20 min, whereas it remained sensitive to endo $\mathrm{H}$ until $60 \mathrm{~min}$ in $16 \mathrm{~d} \mathrm{CEF}$. Post-translational modifications of $\mathrm{N}$-linked mannose-rich chains to complex type chain may account for the difference in the expression of cell surface FN and thus for the difference in cell adhesion capacity to plastic.
\end{abstract}

\section{fibronectin / blosynthesis / adhesion / fibroblast}

Résumé - Blosynthèse de la fibronectine et capacités adhésives des fibroblastes d'embryons de poulet. Les capacités différentes d'adhésion sur le plastique de fibroblastes prélevés à 2 stades du développement embryonnaire chez le poulet (8 et $16 j$ ) sont abolies quand le support est recouvert de fibronectine (FN). Ces résultats suggèrent des différences dans l'expression de la FN et ou des récepteurs membranaires de la FN au cours du processus d'adhésion. Cependant, les 2 populations de fibroblastes expriment le même nombre de récepteurs d'affinité identique. Par contre, l'apparition de la FN à la surface des cellules est plus rapide à $8 j$ (30 min) qu'à $16 j$ (60 min). Ce retard observé dans les fibroblastes de 16 j n'est pas dû à une vitesse de synthèse plus lente de la chaîne polypeptidique, mais plutôt à une modification post-traductionnelle de la FN. En effet, l'utilisation de l'endo $\beta$ - $N$-acétylglucosaminidase $H$ (endo $H$ ) montre que les chaînes oligosaccharidiques de la FN néosynthétisée par les fibroblastes de 16j sont converties en structure complexe beaucoup plus tardivement que celles de la FN des fibroblastes de $8 j$. Ces résultats suggèrent un ralentissement du trafic intracellulaire de la FN à $16 j$ qui peut influer sur la vitesse d'apparition de la $F N$ à la surface cellulaire et sur les capacités adhésives des cellules lors des premières étapes de l'attachement et de l'étalement cellulaire.

fibronectine / biosynthèse / adhésion / fibroblaste 


\section{INTRODUCTION}

Fibronectins constitute a group of highly conserved glycoproteins found in plasma and extracellular matrix. They promote cell attachment and spreading (Yamada, 1983) and many important aspects of embryonic development, including cell growth, migration and differentiation are dependent upon cell-extracellular matrix interactions (Hay, 1982). Recent studies have provided evidence for a dynamic distribution and expression of both fibronectin and FN-receptor during the adhesion process, where fibronectin and its receptor co-localize in stationary fibroblasts (Chen et al, 1986; Roman et al, 1989). Chick embryo fibroblasts exhibit differences in their adhesive capacities on uncoated substratum depending on the stage of development; they behave identically on fibronectin-coated substratum. This could be due to differences in the expression of either the fibronectin receptor or membranebound fibronectin. Differences in the expression of membrane fibronectin have been reported in human fibroblasts during in vitro ageing (Shevitz et al, 1986). Taking advantage of the peculiar behaviour of $\mathrm{fi}$ broblasts in relation to the age of the embryo, we have investigated in the present study the rate of fibronectin synthesis and its expression at the cell surface during adhesion of $8 \mathrm{~d}$ and $16 \mathrm{~d}$ CEF.

\section{MATERIALS AND METHODS}

\section{Cell cultures}

Fibroblasts were obtained from $8 d$ (8d CEF) and $16 \mathrm{~d}$ (16d CEF) old chick embryos using the method previously described by Aubery and Bourrillon (1976). Cells from primary monolayer cultures were used before confluence and were obtained by trypsin-TPCK treatment as previously reported' (Botti et al, 1987).

\section{Adhesion assays}

Cell adhesion assays were conducted as previously described in $\mathbf{2 4}$ well tissue culture plates (Linbro, Poly Labo Paul Block and Cie, Strasbourg) coated or not with $F N(20 \mu \mathrm{g} / \mathrm{ml}$ of human FN) in the absence of serum (Botti et al, 1987). The plates were incubated at $37^{\circ} \mathrm{C}$ for various periods of time. At the end of the incubation period, the plates were washed 3 times with PBS to remove the non-adherent cells. The number of adherent cells was determined after a mild trypsin treatment. In some sets of experiments, the synthesis of endogenous attachment factors was prevented by incubating the cells with $25 \mu \mathrm{g} / \mathrm{ml}$ of cycloheximide for $2 \mathrm{~h}$. The inhibitor was present at the same concentration in all the medias subsequently used.

\section{Binding of iodinated FN}

FN was iodinated as previously described (Codogno et al, 1987). 1 × $10^{7}$ trypsin-treated cells/ $\mathrm{ml}$ were suspended in Dulbecco's modified MEM, $20 \mathrm{mmol} / \mathrm{l}$ HEPES, $2 \%$ bovine serumalbumin $\mathrm{pH}$ 7.4. ${ }^{125} \mathrm{l}-\mathrm{FN}$ at concentrations ranging from $0.1-10 \mathrm{nmol} / \mathrm{l}$ was added to $100 \mu \mathrm{l}$ of cell suspension. The binding mixtures were then incubated for $2 \mathrm{~h}$ at $22^{\circ} \mathrm{C}$. The non-specific binding was determined in the presence of a 100fold excess of unlabelled FN. Results were analysed according to Scatchard (1949).

\section{Biosynthesis of FN}

Eight $d$ and $16 d$ CEF were labelled with $\left[{ }^{14} \mathrm{C}-U\right]$ leucine $(10 \mu \mathrm{Ci} / \mathrm{ml}$, sp act $300 \mathrm{Ci} / \mathrm{mmol}$ CEA, Saclay) for 30,60 and $180 \mathrm{~min}$. The newly synthesized FN was immunoprecipitated from intact cells using anti-human plasma fibronectin antibodies, (Dakopatts Sebia, Issy-les-Moulineaux) according to the method of Tarone et al (1980) and analyzed by polyacrylamide gel electrophoresis. In order to follow the kinetics of FN biosynthesis, 8 and $16 \mathrm{~d}$ CEF were labelled with ${ }^{35} \mathrm{~S}$ methionine $(10 \mu \mathrm{Ci} / \mathrm{ml}$, sp act $1200 \mathrm{Ci} / \mathrm{mmol}$, 
CEA, Saclay) for various times from 15-180 min. Radiolabelled FN was then immunoprecipitated from cell lysate.

\section{Endo $H$ treatment of FN}

Cells were pulsed for $10 \mathrm{~min}$ with $35 \mathrm{~S}$ methionine as described above and chased from $0-24 \mathrm{~h}$ in the presence of $2 \mathrm{mmol} / \mathrm{l}$ methionine. The labelled intracellular FN was immunoprecipitated and aliquots were either untreated (control) or treated with endo- $\beta-N$-acetylglucosaminidase $\mathrm{H}$ (endo $\mathrm{H}$ ) according to the method of Tarentino and Maley (1974). SDSpolyacrylamide gel electrophoresis and autoradiographic analysis were conducted according to Laemmli (1970) and Bonner and Laskey (1974) respectively.

\section{RESULTS}

\section{Cell adhesion}

When plated on a plastic support, 8d CEF adhere more rapidly than $16 \mathrm{~d} C E F$, since $50 \%$ of adhesion was obtained in $110 \mathrm{~min}$ and $150 \mathrm{~min}$ respectively. Complete readhesion ( $80 \%$ of the plated cells) needed $4 \mathrm{~h}$ and $6 \mathrm{~h}$ in 8 and 16d CEF respectively. Whatever the age of embryos, the cells were unable to attach in the presence of cycloheximide. When plated on a FNcoated substrate, $8 \mathrm{~d}$ and $16 \mathrm{~d}$ CEF exhibit identical adhesion kinetics. The adhesion process was almost complete after $60 \mathrm{~min}$ for both fibroblast populations ie $80 \%$ of the cells were attached. The same results were observed in the absence or in the presence of cycloheximide.

\section{FN binding sites on 8-d and 16-d CEF}

Each cell population displays only 1 class of FN-binding sites and the same number of binding sites (550 000 sites/cell) with a $\mathrm{k}_{\mathrm{d}}$ of $1.40 \mu \mathrm{mol} / \mathrm{l}$.

\section{Re-expression of FN at the cell surface}

The ${ }^{14} \mathrm{C}$-leucine-labelled FN was detected from $30 \mathrm{~min}$ in $8 \mathrm{~d}$ CEF and the amount of $\mathrm{FN}$ increased up to $3 \mathrm{~h}$ of re-adhesion assay. In 16d CEF, the labelled FN was detected only after $60 \mathrm{~min}$. Thus, the newly synthesized $\mathrm{FN}$ was expressed earlier at the cell surface in $8 d$ than in $16 d$ CEF (fig 1).

\section{Kinetics of FN biosynthesis}

The rate of ${ }^{35} \mathrm{~S}$-methionine incorporation was identical in $8 d$ and $16 \mathrm{~d}$ CEF from 0 $60 \mathrm{~min}$. Thereafter, a plateau was observed in $8 d$ CEF, and this may represent the equilibrium between newly synthesized FN and secreted FN. In contrast, such a plateau was not observed in $16 \mathrm{~d} C E F$, in rela-

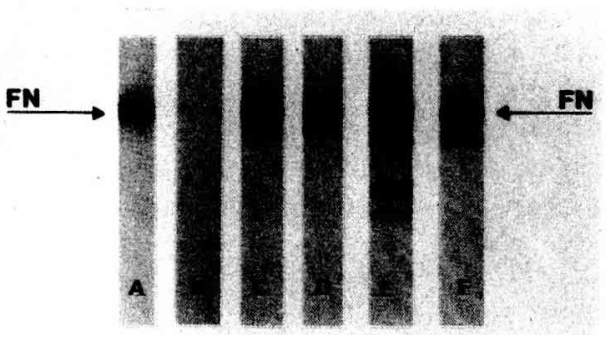

Fig 1. Expression of membrane fibronectin at various times of re-adhesion assay in $8 \mathrm{~d}$ and 16d CEF. ${ }^{14} \mathrm{C}$-leucine-labelled fibronectin was immunoprecipitated at various times with antihuman plasma fibronectin. SDS-polyacrylamide gel electrophoresis was performed on $7.5 \%$ acrylamide gels and analysed by autoradiography: 30 min, A) 8-d, B) 16-d; 60 min; C) 8-d, D) 16-d; $180 \mathrm{~min}$, E) 8-d, F) 16-d.

At 180 min: other bands represent degradation products of fibronectin. 
tion with the later expression of $\mathrm{FN}$ at the cell surface (fig 2).

\section{Endo $H$ sensitivity of FN}

FN was shown to possess at least 6 sites of $\mathrm{N}$-glycosylation substituted. with complex type chain, synthesized in mannoserich precursor form sensitive to endo $\mathrm{H}$ treatment (Olden et al, 1980). FN originated from $8 \mathrm{~d}$ CEF was sensitive to endo $\mathrm{H}$ treatment until $20 \mathrm{~min}$, and then became unsensitive. In 16d CEF, the FN exhibited an endo $\mathrm{H}$ susceptibility until $60 \mathrm{~min}$ after labelling with ${ }^{35} \mathrm{~S}$-methionine (table I). These results suggest that the time of efficient maturation of this secreted glycoprotein from the rough endoplasmic reticulum to the Golgi complex is 3-fold higher in 16d than in $8 d$ CEF.

\section{DISCUSSION}

Fibroblasts obtained from $8 \mathrm{~d}$ and $16 \mathrm{~d}$ old chick embryos exhibited marked differences in their adhesive capacities on plastic support, whereas both $8 \mathrm{~d}$ and $16 \mathrm{~d}$ CEF display identical adhesion properties on FN-coated substratum. Unequal adhesion on plastic cannot be due to a difference in the expression of membrane FN

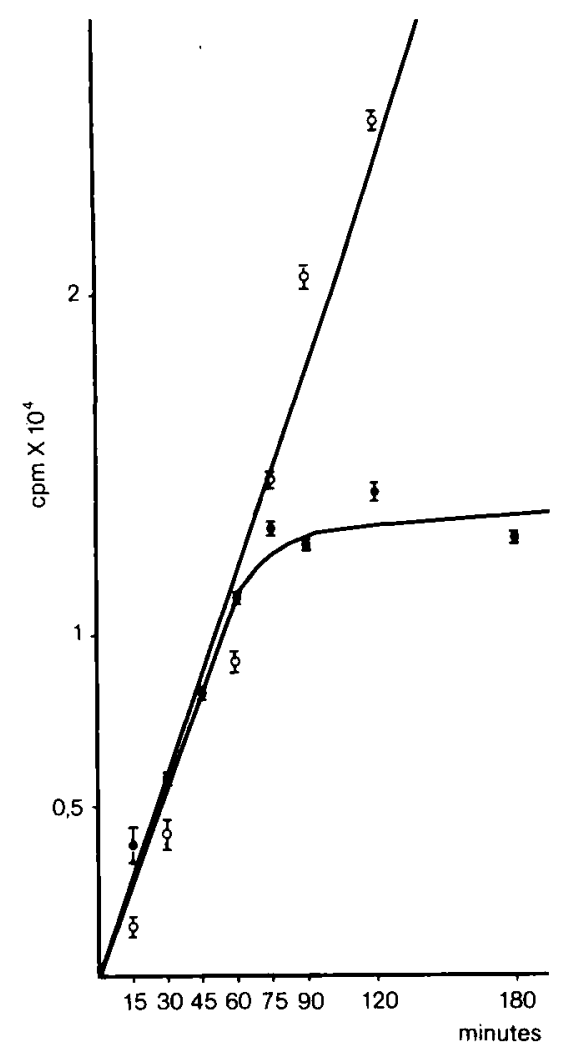

Fig 2. Kinetics of fibronectin biosynthesis in $8 d$ and $16 \mathrm{~d}$ CEF. After metabolic labelling with ${ }^{35} \mathrm{~S}-$ methionine, fibronectin was immunoprecipitated from the cell lysate and the radioactivity was determined using a liquid scintillation spectrometer intertechnique SL 4000. ๑: 8d CEF. O: 16d CEF.

Table I. Fibronectin susceptibility to endo $\mathrm{H}$ treatment in $8 \mathrm{~d}$ and $16 \mathrm{~d}$ CEF.

\begin{tabular}{lcccccccc}
\hline \multicolumn{8}{c}{ Chase time } \\
& $0 \min$ & $10 \min$ & $20 \min$ & $30 \min$ & $40 \min$ & $60 \min$ & $24 \mathrm{~h}$ \\
\hline $8 \mathrm{~d}$ & + & + & + & - & - & - & - \\
$16 \mathrm{~d}$ & + & + & + & + & + & + & - \\
\hline
\end{tabular}

After ${ }^{35} \mathrm{~S}$-methionine incorporation for $10 \mathrm{~min}$ in $8 \mathrm{~d}$ and $16 \mathrm{~d} \mathrm{CEF}$, the labelled fibronectin was immunoprecipitated at various times from $0-24 \mathrm{~h}$ of chase in the presence of $2 \mathrm{mmol} / \mathrm{methionine.} \mathrm{Aliquots} \mathrm{of} \mathrm{immunoprecipitates} \mathrm{were}$ treated with endo $\mathrm{H}$. Untreated and treated immunoprecipitates are subjected to SDS-5\% polyacrylamide gel electrophoresis followed by autoradiography. The susceptibility to endo $\mathrm{H}$ treatment was estimated from the modification of FN molecular weight. 
receptors since $8 d$ and $16 d$ CEF expressed an identical number of $F N$ receptors with similar affinity. In addition, FN interacts with high molecular weight membrane proteins (150-125 kDa) unsensitive to trypsin treatment in both $8 \mathrm{~d}$ and $16 \mathrm{~d}$ CEF (Botti et al, 1987). A difference in the FN expression at the cell surface is the most likely explanation. This hypothesis was supported by the results reported here since we observed that FN reappeared more rapidly in $8 d$ than in $16 \mathrm{~d}$ CEF. This difference in the $\mathrm{FN}$ re-expression at the cell surface is not due to a difference in the biosynthesis rate of the polypeptide chain. Like glycoproteins destined to secretion, $\mathrm{FN}$ is synthesized in the rough endoplasmic reticulum (RER) where asparagine linked mannose-rich built up on dolichol are transferred to the polypeptide backbone and trimmed into a complex chain along their passage in the Golgi apparatus. Preliminary studies showed that the transfer en bloc of oligosaccharide chain to the polypeptide occurred at almost the same rate in $8 d$ and $16 \mathrm{~d}$ CEF (data not shown). Thereafter, the delayed sensitivity to endo $\mathrm{H}$ of $16 \mathrm{~d} F N$ was due to steps occurring during the transit between the RER and median Golgi. Moreover, differences in the late maturation of complex oligosaccharides in the trans Golgi could not be excluded. Nevertheless, no important variations in complex type oligosaccharides of $F N$ between 8d and 16d CEF were observed (data not shown). From the data presented here we can conclude that early differences in the post-translational modification of $\mathrm{N}$-glycans influence the CEF adhesion.

\section{ACKNOWLEDGMENTS}

This work was supported by grants from $\mathbb{N}$ SERM, UFR Biomédicale des Saints-Pères and Fondation pour la Recherche Médicale.

\section{REFERENCES}

Aubery M, Bourrillon R (1976) Cell growth and thymidine incorporation changes induced by dolichos lectin in fibroblasts at various stages of differentiation. Cell Differ 4, 67-71

Bonner WM, Laskey RA (1974) A film detection method for tritium labelled proteins and nucleic acids in polyacrylamide gels. Eur $\mathrm{J}$ Biochem 46, 83-88

Botti J, Doyennette-Moyne MA, Gouet E, Aubery M, Codogno P (1987) Alterations of tibroblast interactions with fibronectin and laminin during chick embryo development. Cell Biol Int Rep 11, 849-859

Chen WT, Wang J, Hasegawa T, Yamada SS, Yamada KM (1986) Regulation of fibronectin receptor distribution by transformation - exogenous fibronectin and synthetic peptides. $\mathrm{J}$ Cell Biol 103, 1649-1661

Codogno P, Doyennette-Moyne MA, Aubery M (1987) Evidence for a dual mechanism of chick embryo fibroblast adhesion on fibronectin and laminin substrata. Exp Cell Res 169, 476-489

Hay ED (1982) In: Cell Biology of Extracellular Matrix. Plenum Press Publishing Corp. New York, $417 \mathrm{pp}$

Laemmli UK (1970) Cleavage of structural protein during the assembly of the head of bacteriophage T4. Nature (Lond) 227, 680-685

Olden K, Hunter VA, Yamada KM (1980) Biosynthetic processing of the oligosaccharide chains of cellular fibronectin. Biochim Biophys Acta 632, 408-416

Roman J, Lachance RM, Broekelmann TJ, Kennedy CRJ, Wayner EA, Carter WG, Mc Donald JA (1989) The fibronectin receptor is organized by extracellular matrix fibronectin: implications for oncogenic transformation and for cell recognition of fibronectin matrices. J Cell Biol 108, 2529-2543

Scatchard C (1949) The attraction of proteins for small molecules and ions. Ann N Y Acad Sci $51,660-672$

Shevitz J, Jenkins CSP, Hatcher VB (1986) Fibronectin synthesis and degradation in human fibroblasts with ageing. Mech Ageing Dev 35, 221-232 
Tarentino AL, Maley F (1974) Purification and properties of an endo $\beta$ - $\mathrm{N}$-acetylglucosaminidase from Streptomyces griseus. J Biol Chem 249, 811-817

Tarone G, Prat M, Comoglio PM (1980) Identification and partial characterization of five membrane glycoproteins of BHK fibroblasts. $J$ Membr Biol 53, 55-61

Yamada KM (1983) Cell surface interactions with extracellular materials. Annu Rev Biochem 62, 761-799 